\title{
PALAMEDEA CORNUTA.
}

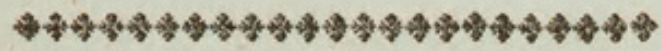

CharaCter Genericus.

Rostrum conicum, mandibula superiore adunca. Nares ovatæ,

Pedes tetradactyli, fissi.

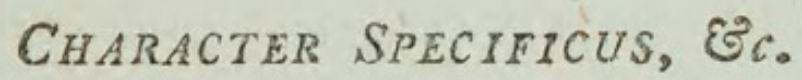

PALAMEDEA nigra, subtus alba, alulis bispinosis, fronte cornuta.

PALAMEDEA cornuta. P. alulis bispinosis fronteque cornuta.

Lin. Syst. Nat. p. 232.

Gralla.

Avem grandem et magnificam depinximus in America Australi calidiori generatam, locorum, ut plurimum, paludosorum incolam, variorum reptilium prædatricem. Præcipue eam insignit cornu quasi callosum et acuminatum, e fronte assurgens in altitudinem trium seu quatuor unciarum. Alta est ipsa avis circiter quatuor pedes. E rarioribus est quæ Grallce nominantur, nec sæpe in Europam invehitur. Vocem emittere dicitur raucam et clamosam. 


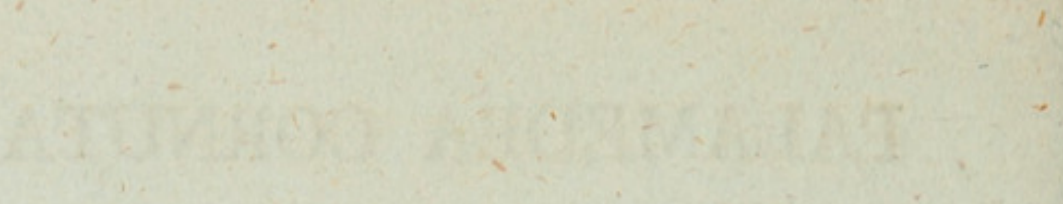




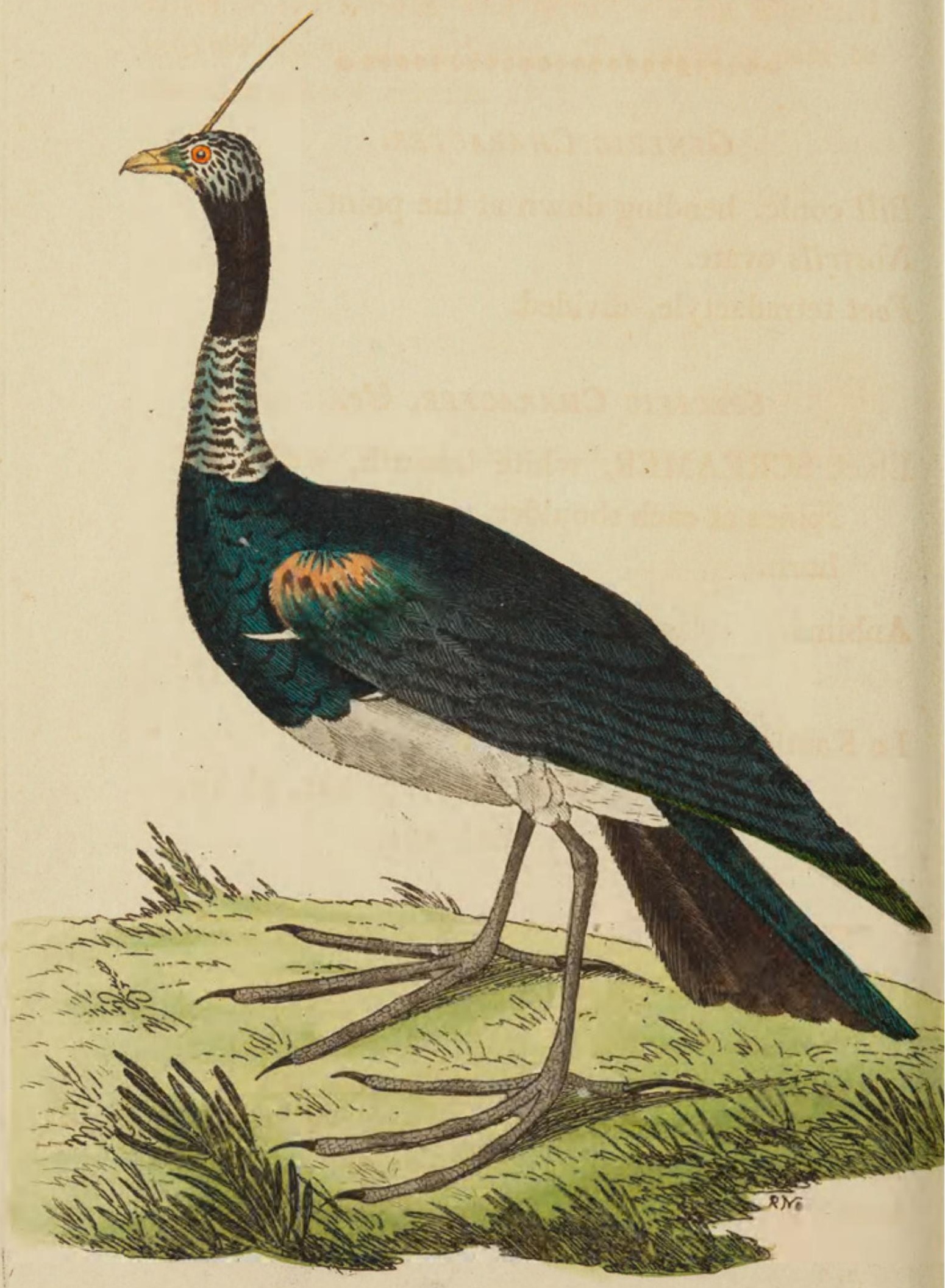




\section{THE \\ HORNED SCREAMER.}

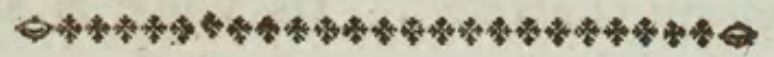

GENERIC CHARACTER.

Bill conic, bending down at the point。 Nostrils ovate.

Feet tetradactyle, divided.

\section{SPECIFIC CHARACTER, E'C.}

Black SCREAMER, white beneath, with two spines at each shoulder, and slender frontal horn.

Anhima.

$$
\text { Will. orn. p. } 276 \text {. pl. } 47 .
$$

Le Kamichy.

Buff. ois. 7. p. 335. pl, 18.

Pl. Enl. 451 .

The large and stately bird here represented is a native of the hotter parts of South America, residing in marshy places, and feeding principally on various kinds of reptiles : its most striking external character is the upright callous process or pointed horn on the top of the head, which rises to the G 2

height 
height of three or four inches. The general height of the bird is about four feet. It is one of the rarest of the Gralle, and is but seldom imported into the European continent. Its voice is said to resemble a harsh scream. 


\section{$2 \mathrm{BHL}$ Biodiversity Heritage Library}

Shaw, George. 1803. "The Horned Screamer, Palamadea cornuta [PI. 565]." The Naturalist's Miscellany 14(CLXIII), https://doi.org/10.5962/p.311010.

View This Item Online: https://www.biodiversitylibrary.org/item/278723

DOI: https://doi.org/10.5962/p.311010

Permalink: https://www.biodiversitylibrary.org/partpdf/311010

\section{Holding Institution}

Museums Victoria

\section{Sponsored by}

Atlas of Living Australia

\section{Copyright \& Reuse}

Copyright Status: Public domain. The BHL considers that this work is no longer under copyright protection.

This document was created from content at the Biodiversity Heritage Library, the world's largest open access digital library for biodiversity literature and archives. Visit BHL at https://www.biodiversitylibrary.org. 